\title{
Supporting the President in a \#NotMyPresident Context: Experiences of College-Aged Trump Supporters at a Southern University
}

\author{
Madison Adams \\ Southwestern University, USA \\ Texas A\&M University, USA
}

DOI: https://doi.org/10.18778/1733-8077.17.4.05

Keywords:

Identity;

Neutralization

Theory;

Conservatism;

Sexual

Misconduct;

Donald Trump

\begin{abstract}
In light of sexual misconduct allegations involving the former president of the United States, this study analyzes the reasons some university students provide for their continued support of Donald Trump. Relying on ten semi-structured qualitative interviews with college students who align with the president, this paper identifies three interrelated stages making up a model of support. First, students identify their conservative worldviews as helping to explain their initial support of Trump. Second, given the numerous accusations leveled against the president in the media, students readily use neutralization tactics to counter these narratives and rationalize their continued support. Finally, they feel vilified at their university and elsewhere for supporting Trump, and they find it necessary to conceal their opinions. Such experiences do not contribute to them questioning their beliefs. On the contrary, they lead to more entrenched and rigid support of the president. By identifying this three-stage process and applying neutralization theory to better understand it, this paper contributes to the existing sociological literature on the persistence of conservatism in the United States today.
\end{abstract}

Madison Adams is a sociology doctorate student at Texas A\&M University. Her research interests broadly include qualitative studies of gender inequality, culture, and politics. Her ongoing research explores the relationship between culture and sexual harassment in higher education.

email address: Adams5@tamu.edu

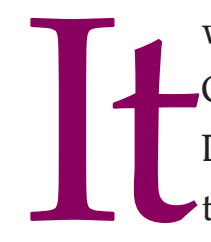

was an outcome that shocked the world. On the evening of November $8^{\text {th }}, 2016$, Donald Trump was elected as the forty-fifth President of the United States. His election was met with widespread protests across the nation as many took to the streets and Twitter with the phrase \#NotMyPresident. By mid-afternoon on January $9^{\text {th }}$, \#NotMyPresident was tweeted 
more than 490,000 times (Frumin 2016). In the weeks and months that followed, emotions ranged "from panic to disbelief, to fear, to anger, to hope that Americans will not give up and continue to fight for change" (Frumin 2016). Conservative journalists frame the \#NotMyPresident protests as an indication that liberals were sore losers, whiners, and not respectful of the democratic process (Gainor 2016; Gainor 2017; Reimer 2017). One such journalist, Reimer (2017), describes the protests as "extraordinarily disrespectful to the leader of our nation" and as setting a "dangerous political precedent." Donald Trump's election was certainly not the beginning of partisan acrimony in the US; yet, his election further polarized the nation and is arguably one of the most contested presidencies to date.

Some of the protests that mark Trump's presidency focus on a host of investigations, lawsuits, and allegations against Trump, including, but not limited to, accusations of sexual misconduct (Abrams 2019). Notably, at least twenty-six women accuse President Trump of sexual misconduct dating back to the 1970s when Trump is alleged to have groped Jessica Leeds on a flight (Keneally 2019; Relman 2020). More recently, several women accuse Trump of sexual harassment and assault throughout the 1990s and 2000s. Cassandra Seales accuses Trump of sexually assaulting her during the 2013 Miss Universe competition (Keneally 2019). Trump's reaction to his numerous accusers is asserting that all of the women are lying and that they are not attractive enough for him to assault (Keneally 2019; Relman 2020). Of the twenty-six women who have come forward, only two have taken legal action against President Trump (Keneally 2019). E. Jean Carroll, one of Trump's accusers, claims that her move to sue is the reason she was fired from her columnist position at Elle, which she held for 26 years (Grady 2020).
In addition to sexual assault allegations, Trump is also known to have made lewd and sexist comments about women. For example, in a 2005 recorded conversation with Billy Bush, Trump brags, "when you're a star, they let you do it. You can do anything to women," including "just start kissing them...I don't even wait" and "grab em' by the $\mathrm{p}^{* * *} \mathrm{y}^{\prime \prime}$ (Fahrenthold 2016). Also, in this recording, Trump recounts how he aggressively pursued a married woman with little to no regard for her consent (Fahrenthold 2016).

Despite Trump's deeply troubling and offensive comments about and actions toward women, he still has a fervent support base that includes conservative college students. Following the 2016 election, these students showed their support in numerous ways, including chalking pro-Trump messages on their respective campuses, disrupting anti-Trump protests, and some even showed support by verbally and physically attacking minority students (Dickerson and Saul 2016; Rogers 2016). Other university students who endorse Trump did so more quietly and behind the scenes. In fact, in 2016, Trump "surpassed expectations, earning 37 percent of the millennial vote" (Spencer 2019).

Given that college students can be a major deciding factor in presidential elections (Spencer 2019), sociologists need to understand why some university students continue to support President Trump, particularly in the face of his numerous sexual misconduct allegations. Additionally, for a host of reasons, including how experiences in academic settings can challenge or reinforce such beliefs, it is important to know how these students navigate their conservative political identities on their university campus. The current study utilizes interviews with college-aged Trump supporters to investigate these 
timely issues and identifies three interrelated stages of support (initial, ongoing, and consequences). I rely on previous scholarship on conservative identity, neutralization theory, and alienation to explain how Trump-supporting university students account for their initial and continued approval of the president and the reported consequences of endorsing Trump at a Southern university, as well as how these perceived costs only strengthen their belief in Trump.

\section{Literature Review}

This research draws from three main bodies of literature, including conservative identity, neutralization tactics, and alienation. A conservative identity describes what leads interviewees to initially supporting Trump. Secondly, the neutralization theory explains how interviewees rationalize the ongoing approval of Trump. Lastly, participants report experiencing alienation from others on their campus as a direct consequence of endorsing Trump, which, for some, confirms their approval of him.

\section{Conservative Identity}

Much of the research on conservative identities was conducted by scholars in the field of political science (Gross, Medvetz, and Russell 2011; Kidder 2016). Indeed, there is a noticeable lack of sociological research examining conservatism and conservative political identity resulting in a relatively vague sociological definition of what constitutes American conservatism (Gross et al. 2011; Kidder 2016; Merriman 2019). The sociological research that does exist suggests that conservatives tend to resist progress, embrace traditional values, and support a free market (Gross et al. 2011; Merriman 2019). In addition, a conservative identity is shown to include Chris- tianity, a pro-life stance, and an economic/business mindset (Kidder 2016; Adams 2019; Berlinerblau 2019; E. Johnson 2019; Merriman 2019).

Scholars also find connections between religion, especially white evangelical Christianity, and political conservativism, a pattern that appears to have become especially pronounced in recent years, particularly in terms of Trump (Binder and Wood 2013a; Adams 2019; Berlinerblau 2019). In fact, white evangelical Protestants report having the highest endorsement of Trump-7 in 10 white evangelicals say they approve of how Trump is handling the presidency (Schwadel and Smith 2019). More specifically, Trump is seen by many of his evangelical supporters as a protector of evangelical Christianity and as God's candidate (Adams 2019; Berlinerblau 2019). Adams (2019:254) argues that,

by presenting Trump as God's man, conservative Christians no longer need to justify his questionable past and vile behavior. God is in control, and thus pious consciences are apparently cleansed, and support for Trump is legitimate.

The Christian aspect of the conservative identity allows some supporters to disregard Trump's past for the sake of having what they perceive as a Godly candidate (Adams 2019).

Additional factors, such as race (whites), gender, a pro-business stance, and an anti-choice, or what others may call a pro-life position, prove to be key components in conservatives' support of Trump (Kidder 2016; Blackett 2017; Edgell 2017; Junn 2017; Tien 2017; Hills 2018; Pruitt 2018). However, most of this previous work relies on surveys or content analysis and also tends to ignore the experiences of university students in their work. Previous litera- 
ture also tends to overlook conservatism amongst college-aged people. This study addresses these gaps, in part, by relying on interviews with college students who identify as conservatives that support Trump. By doing so, I also can identify some of the processes involved in why people persistently claim to approve of Trump.

\section{Neutralization Tactics}

Neutralization theory was originally coined by Sykes and Matza (1957) to describe how criminals reject perceiving themselves as delinquent and relieve any guilt associated with an action deemed delinquent. Furthermore, Sykes and Matza (1957) establish five different neutralization tactics, such as individuals denying responsibility by claiming their actions are caused by forces outside of their control or denying having caused harm to neutralize their behavior (Boyle and Walker 2016). Also, turning the victim into someone deserving of the crime allows individuals to justify their actions (Boyle and Walker 2016). Another strategy is to direct attention away from their misdeeds by shifting the focus to perceived wrongdoings of others, especially those against them (Kaptein and van Helvoort 2019). Lastly, claiming that their behavior serves the greater good or protects their in-group is a way to appeal to higher loyalties (Kaptein and van Helvoort 2019).

More recently, sociologists apply neutralization theory to numerous other arenas, including the behaviors and attitudes of university students. For example, Boyle and Walker (2016) examine how college students use neutralizing strategies to downplay and excuse sexual violence (Boyle and McKinzie 2015; Boyle and Walker 2016). Other studies on neutralization explore a variety of topics, including the minimization of sexting on campus, students' neutralization of state crime, and even green consumers rationalizing the use of environmentally harmful products (Klein and Lavery 2010; Atkinson and Kim 2014; Renfrow and Rollo 2014). More broadly, researchers find that when reporting on Trump's sexual misconduct allegations, media sources engage in neutralizing techniques by minimizing his accusers' stories (Schneider and Hannem 2019). Silva (2019) also finds that Trump's racism is neutralized in multiple ways through public posts on social media. Scholars explain women's support of Trump through the endorsement of hegemonic masculinity, religion, sexism, and racial resentment (Jaffe 2018; Setzler and Yanus 2018; Vescio and Schermerhorn 2020). Jaffe (2018) categorizes women who voted for Trump into types: the wealthy, the white supremacist, the evangelical, the security voter, and the worker. Lastly, previous literature has identified tactics of denying, justifying, and legitimatizing racism, such as the strategy to present a positive in-group presentation or to reformulate a controversial event (van Dijk 1992; van Leeuwen and Wodak 1999). One study finds that "bitchifying" Hillary Clinton was a common tactic amongst Trump supporters (Erichsen et al. 2020). Overall, scholars find that neutralization tactics justify the continuation of knowingly harmful behaviors (van Dijk 1992; van Leeuwen and Wodak 1999; Klein and Lavery 2010; Atkinson and Kim 2014; Renfrow and Rollo 2014; Boyle and McKinzie 2015; Boyle and Walker 2016; Schneider and Hannem 2019; Silva 2019; Erichsen et al. 2020).

I argue that neutralization theory can explain how conservative students can acknowledge the harm Trump has perpetrated while simultaneously still endorsing and defending him. Thus, even though Trump is associated with behaviors that many 
Christians are usually critical of, such as offensive and lewd language and sexual misconduct, their support remains unwavering.

\section{Perceived Sense of Alienation}

Originally coined by Karl Marx (2013), alienation describes the state of industrial proletariat workers under capitalism. More recently, sociologists apply the term more widely to include non-workers who feel isolated, marginalized, and different from society (Seeman 1959; Binder and Wood 2013b; Pruitt 2018). For instance, some researchers examine alienation among college students, particularly those who are not part of hegemonic groups, such as racial, ethnic, and religious minorities (Shammas 2015; Gummadam, Pittman, and Ioffe 2016; Tachine, Cabrera, and Yellow Bird 2017). Others use alienation to help explain Trump's election. However, they largely focus on how reported feelings of alienation (racial and religious) led some voters to support Trump in the 2016 presidential election (Hills 2018; Pruitt 2018). Specifically, some voters feel as though Trump is finally letting them into politics where previously they have felt left out of the political realm (Hills 2018; Pruitt 2018).

The few scholars that address experiences of conservative students find that they face a hostile political climate, alienation, and marginalization both in and out of the classroom (Munson 2010; Binder and Wood 2013b; Kidder 2016). Moreover, conservatives often see themselves as political minorities on their college campuses (Munson 2010; Binder and Wood 2013b; Kidder 2016). Similarly, studies find that white men also perceive themselves as racially oppressed or alienated by denying white privilege and adhering to color-blind ideologies (Cabrera 2014; Kolber 2017).
The current study fills gaps in the existing literature by honing in on experiences of college Trump supporters to understand what role their conservative identities play in their political decisions, how they implore neutralization tactics to excuse Trump's sexual misconduct and sexist rhetoric, and by investigating how they perceive a sense of alienation being a direct result of their support for Trump. Rather than relying on content analysis, this study utilizes interviews to gain important insights into college-aged conservatism, which other methodologies have not captured. This paper also explores how alienation sustains and furthers their conservative identities. Further, this paper is unique in its consideration of how conservatism and alienation act as motives in supporting and neutralizing Donald Trump. Overall, this study adds to the field of sociology by providing important insight into the current political tensions on college campuses and by explaining the process by which conservative identities persist and strengthen even in the face of controversy.

\section{Methodology}

This qualitative study relies on ten in-depth, semi-structured interviews with college students who support Donald Trump. The focus for this paper is a university that has the reputation for being relatively progressive. Interviews took place over the phone and in person at semi-public areas around the campus, such as the library. Interviews were conducted between March and September 2019 with a total of ten hours and fifty-two minutes of interview hours. Interview length ranges from forty-one minutes to one hour and fifty minutes with the average interview length being an hour and five minutes. Participants were found through reaching out to the college Republicans group on 
campus, as well as posting a recruitment statement on the campus newsletter. Snowball sampling was then utilized to find additional interviewees for the study.

The interview schedule (see: Appendices) consists of five sections to explore why participants report continuing to support the president in light of recent scandals and the perceived consequences of this support on campus. Participants are first asked background questions about what role politics played in their upbringing and family if any at all. The second section focuses on their personal views regarding Trump. These include questions about recent scandals surrounding the president, as well as his performance thus far. The third section explores their relationships and interactions on campus with peers and faculty. In the fourth section, questions focus on the interviewees' hopes for the future of politics, beliefs about women's rights, and how Trump could impact politics. Finally, participants were asked a series of basic demographic questions, such as their age, race, hometown, and class status.

The sample (see: Table 1 [Appendices]) consists of six women and four men who are between the ages of eighteen and twenty-two. All interviewees attend the university that is the focus of the study. A total of eight interviewees identify as white, and two identify as white and Hispanic. All ten participants report supporting Trump's political agenda, with five participants belonging to the Republican party and five identifying as Independents. Finally, in terms of the economic class of the interviewees, two students identify as upper-class, five reside in the upper-middle-class, and three identify as residing in the middle-class at the time of the interview.
Interviews were conducted, digitally recorded, and transcribed by the author. I used an iterative inductive coding process. I read through each transcribed interview multiple times, identifying three major themes, coding relevant excerpts, and placing them into appropriate themes. After I did this, two classmates separately read and coded clean copies of all of the transcribed interviews. I then met individually with each of the two classmates, and we verified our respective coding, discussed discrepancies, and agreed on which excerpts fit in each thematic category. As a result of this collaborative process, a total of 127 pages of interviews were analyzed and coded into categories in a multi-stage process by three senior undergraduate sociology majors. At the end of this process, I identify conservative identity, neutralization tactics, and a perceived sense of alienation as the three major themes.

All of the interviewees explicitly label an aspect of their upbringing as conservative, which made up the conservative identity code. The conservative identity category is marked by mentions of religion, business, and traditional values. For instance, Andrea, a white freshman's comment, "one thing that has been very fundamental in how I've been raised has been core beliefs surrounding faith and religion," was coded as conservative identity. Additionally, any mentions of an influential conservative family member were also coded as conservative identity.

Neutralization tactics consist of reasonings interviewees provide for their continued support of Trump, even in the face of controversy. For instance, Bartholomew, a white freshman, states, "in general, I think he's done more good for the country than harm." His statement is coded under neutralization tactics because he neutralizes the harm Trump has 
caused by claiming that Trump's positive impact outweighs the bad.

A common consequence of supporting Trump amongst interviewees is the loss of relationships or perceiving the university campus as against them. The mention of this consequence is coded as a perceived sense of alienation and includes dialogue, such as Anne, a white junior's comment, "[if] you voted for Trump, it's like leprosy written across your forehead."

My positionality as a white, college-aged woman with conservative family members who support Trump guided the research process from start to finish. During interviews, I was able to create a level of rapport and trust with interviewees as I could personally relate to their responses and foster a safe environment for them to share their views. Additionally, my positionality was useful during data analysis because I was able to detect nuances relating to a conservative identity as I sifted through the data. Additionally, my positionality furthered my understanding of the data because I have previously been exposed to rationalizations similar to the interviewees', which allowed me to formulate themes.

\section{Historical Context}

Since the 2016 presidential election, there is a rise in political tensions among students at university campuses (Cohen 2017; J. Johnson 2019). For instance, a protest at the University of Washington in response to Milo Yiannopoulos' talk on campus ended in a shooting (J. Johnson 2019). In another incident at Claremont McKenna College, conservative speaker, Heather Mac Donald, was blocked from speaking due to a large group of students protest- ing her views on the Black Lives Matter movement (Wootson 2017). Despite such resistance to conservative speakers at American universities, conservative college organizations remain vocal and continue to prevail, such as the University of Maine's College Republicans, who have taken a harsh anti-immigration, anti-climate change, and "America first" stance (Anderson 2020). Recently, Trump addressed conservative Millennials at a Turning Point USA conference in which he rallied against looming impeachment, arousing thousands of college-aged supporters (McGraw 2019).

Interestingly, even with growing numbers, some conservative students at several universities report being marginalized and believe they face discrimination from faculty and peers for their conservative beliefs (Hartocollis 2016; Woessner and Maranto 2019). In fact, one survey finds that students on both the political left and right believe conservative students are less able to speak freely on campuses (Jones 2018). Although their candidate won, some conservative students say that they are under threat and need conservative safe spaces as they often find themselves at odds with the rest of campus (Kidder 2016; Hartocollis 2016).

Following the election, the university in this study, which has a relatively liberal reputation, experienced multiple incidents that could classify as hate crimes. These include pro-Trump chalked messages that consist of phrases like "you aren't safe here" and "build the wall." Additionally, there are reports of cars with Trump stickers being keyed or vandalized. Students who feared for their safety on campus reached out to administration, asking them to address the polarization on campus. In an email to the administration, one student says, "The truth is, we are scared. We are sad. We are exhausted. The 
climate that is quickly escalating on campus is what we have deemed a state of emergency."

The university president attempted to mollify the polarization by sending out a campus-wide email. This email includes a reminder of what the university defines as a hate crime and an attempt to unite the student body. Although this particular campus flashpoint has since receded, as my findings indicate, political tensions among some students continue in more subtle and intermittent ways. According to popular press articles, these patterns appear to play out on university campuses across the country (Dickerson and Saul 2016; Hartocollis 2016; Jones 2018; Anderson 2020).

\section{Findings}

I organize the results into three interrelated sections. The first focuses on how interviewees' resonance with conservative worldviews drives their initial support. The second examines interviewees' use of neutralization tactics to rationalize their continued support. Finally, the third theme explores the alienation interviewees perceive as a consequence of their support.

\section{Resonance with Conservative Worldview}

All ten interviewees resonate with a conservative worldview, which includes a combination of having traditional values, being Christian, having a pro-business mindset, and being pro-life (Gross et al. 2011). These dimensions of participants' conservative identity are crucial in facilitating their initial approval of Trump as President.

The vast majority of the interviewees (9 out of 10) describe their family and their upbringing as con- servative and/or emphasizing what they consider to be traditional values. Specifically, the conservative positioning of the interviewees' family members influences their political views and contributes to their support of Trump. In contrast, Bartholomew, a white freshman, explains that his parents hold differing views and mostly kept politics out of the house and allowed him to explore and form his opinions and beliefs. Importantly, these participants perceive Trump as embodying and upholding the conservative values they initially develop in their childhood. For example, Andrea, a white freshman, states, "[President Trump] reflects the views that I think I've grown up with." Hannah, a white senior, expresses a similar sentiment saying,

A lot of people like to say that he's not conservative because of the things that he's said, but I believe that he does support traditional, conservative values. Values like we should take care of our country first.

Their conservative or traditional upbringing led interviewees to search for similar values within political leadership. Throughout his campaign, Trump appeals to the conservative identity and claims to uphold traditional values. For instance, Trump (2018) describes himself as protecting these traditional or "American" values, which he outlines as religious liberty, the sanctity of life, and reducing the burden of the government.

Religion is often cited as an integral part of the conservative outlook, and many view Trump as God's candidate and the protector of Christian values (Adams 2019; Berlinerblau 2019). Further, Trump (2018) describes his agenda as protecting religious liberties by bringing religious groups back into the field of politics and by implementing regulations to ensure that healthcare providers do not have to violate their 
religious or moral beliefs. Notably, Trump's agenda mainly benefits Christians, while his notorious travel ban and push to bring prayer back into schools threatens Muslims' and others' civil liberties, thus implying that Trump is protecting Christian hegemony (Kaplan et al. 2019; Lemire and Schor 2020).

The second dimension of the conservative perspective that proves crucial for students' initial support of Trump is their religious beliefs. Out of the ten interviewees, eight describe themselves as religious and as growing up in a religious home. More specifically, five participants label themselves as Christian, two students identify as Catholic, and one interviewee describes himself as Mormon. Of the remaining two participants, one did not specify, and the other labels himself as non-religious. Six out of the eight religious interviewees explicitly identify their religious beliefs as a reason for their initial endorsement of Trump. For instance, Hannah, a white/ Hispanic senior, explains,

I like that he's more traditional in the sense that he supports Christianity as our predominant Western religion. I just believe in those values, and I think that he upholds them as well.

Andrea, a white freshman, also expresses the role Christianity plays in her support stating, "because in the house that I was raised in it was a very active thought to think that our politics should fall in line with what we believe in our faith." Andrea expresses an intersection of Christianity and policies that Trump appeals to. Moreover, Trump gears himself towards the conservative party by taking on what some perceive as a Christian mindset.

Having a pro-life stance is the third dimension of conservative identity that helps to explain many of the participants' initial support of Trump. Half of the interviewees identify this issue as being critical in their support. Specifically, they mention his attempts to defund Planned Parenthood and roll back Roe V. Wade. Moreover, students connect their religion with pro-life policy (E. Johnson 2019). Kendall expresses her stance, explaining, "he's pro-life. I support that." Similarly, Bartholomew states, "he's tough on abortion. I definitely lean pro-life." This connection is one factor the interviewees use to explain their approval of Trump.

Having an economic or business mindset is the last dimension of a conservative identity that is important among participants. Specifically, four of the ten interviewees reveal that one of the main reasons that they support Trump is because they believe he is improving the unemployment rate, boosting the economy, and helping American businesses. Anne, a white junior, explains,

It probably has to do with the fact that my dad is business, my mom is accounting. I was raised with business in my blood. I am very business, I really enjoy it. I love economics...It's just how I am, so that's probably played a big role into it.

Anne and other interviewees appreciate that Trump is a businessman with a focus on the economy. Similarly, in his qualitative study on the conservative identities of college Republicans, Kidder (2016) finds that conservative students value a free market and emphasize economics and business. Ultimately, the fact that Trump is a businessman contributes to some university students' approval of him.

Overall, a resonance with a conservative perspective, which consists of a conservative upbringing, a conservative Christian identity, a pro-life stance, and 
a pro-business mindset, is an essential reason why some university students state that they initially supported Trump as president. Andrea encapsulates the importance of these dimensions of her conservative identity in her approval of Trump when she explains,

I think that he falls in line with the way that my family has raised me to believe, which is very business intensive, economically driven, and religiously kind of backed.

Prior scholars argue that Trump is seen by white Evangelicals as protecting and representing conservatism, which is often associated with whiteness (Blackett 2017; Edgell 2017; Junn 2017). Andrea and other students perceive Trump as upholding and protecting various dimensions of their conservative identity. As a consequence, they throw their support behind him. Given the allegations about Trump's sexual misconduct, would their support for him waver, particularly given that such accusations seem to run counter to some of their stated conservative values?

\section{Neutralization Tactics}

Interviewees demonstrate various forms of positive self-presentation as a means to justify or deny Trump's sexism (van Dijk 1992). Specifically, they utilize the neutralization tactics of denying injury, shifting blame, and appealing to higher loyalties to absolve Trump of guilt. Throughout the interviews, they acknowledge that Trump and their support for him may be perceived as deviant or harmful. However, all of the interviewees report continuing to embrace Trump, even in the face of multiple allegations of sexual misconduct. Although previous research finds that conservatives are less likely to find the sexual misconduct of Republican politicians as problematic, much of this work fails to explain why (van der Linden and Panagopoulos 2019). Literature on the denial, justification, and legitimation of racism reveals that people engage in several tactics to rationalize and reformulate harmful behaviors (van Dijk 1992; van Leeuwen and Wodak 1999). Similarly, my findings indicate that conservative university students engage in various forms of neutralizing techniques that minimize the significance of these allegations and allow them to justify their continued endorsement of Trump.

Similar to van Dijk's (1992) work on the denial of racism, participants employ neutralization tactics to deny Trump's sexism and sexual misconduct. When asked about whether Trump was guilty of sexual misconduct, all participants say no, and instead blame factors beyond his control, which serves to absolve him of responsibility and relieve their guilt for approving of him. For example, John, a white sophomore, in response to Trump's sexist rhetoric, states, "that is his generation, and that was just tradition, so they might not view it as sexist because that's how they were raised." Here, John justifies Trump's misogyny, sexist beliefs, and actions on his age, excusing his sexism as an artifact of his age group and upbringing.

Other interviewees explain away his sexism by stating that it was simply his status as a wealthy man in power, which caused Trump to say, "grab them by the $\mathrm{p}^{* * *} \mathrm{y}$." More specifically, Carlos blames male locker-room culture and the tendency for men to boast about sexual pursuits, which is only amplified by wealth. Hannah, a white senior, points to the possibility that Trump was just revealing the truth when she states, "there are women like groupies that follow rich and powerful men that throw themselves at them." By claiming that factors outside of Trump's control are to blame for his sexist behaviors and comments, such strategies exonerate Trump from any responsibility. 
The vast majority of students (8 of 10) also emphasize innocent until proven guilty, which sustains Trump's lack of responsibility by denying injury. For example, when asked about the accusations against Trump, Anne, a white junior, explains, “I completely understand that he has probably done some bad things, but I am not going to say he is guilty until there is hardcore proof." Jack, a white junior, also believes in due process, stating, "there needs to be due process of law. You can't just take someone's word for it. There has to be evidence." Emphasizing innocent until proven guilty when asked about Trump's sexual misconduct allegations allows interviewees to see Trump as innocent and thus continue approving of him.

Participants also appeal to higher loyalties by downplaying the significance of Trump's alleged sexual misconduct by pointing to his supposed victories. For instance, some interviewees, like Bartholomew, John, and Hannah, say that instead of focusing on Trump's sexual misdeeds, people should be paying more attention to how Trump is helping the economy and creating more jobs for women. Three out of the ten students negate claims that Trump is sexist by explaining that he has benefitted women or the economy. Furthermore, they explain that Trump has appointed more women into office than Obama did. For instance, John, a white sophomore, states,

He did appoint a female CIA director, and that was a big step for CIA history... and that was very good for women's rights...so I don't think he's necessarily sexist where he degrades women all the time.

Interviewees can disregard the harm of Trump's sexist commentary by focusing on a few actions that may or may not have benefitted women.
Overall, participants utilize a denial of injury strategy to minimize or dismiss the seriousness of Trump's sexual misconduct accusations. Instead, they point to his alleged economic victories and continue to voice unwavering support for him. For example, Bartholomew points out that, "[Trump] has been really good for minorities in terms of economic development and unemployment." This pattern of focusing on a strong economy and boasting that Trump is responsible for it is similar to how social media posts neutralize his continued racist rhetoric, as well (Silva 2019).

Similarly, the majority of interviewees (8 of 10) use a denial of victim strategy to neutralize the seriousness of Trump's sexual allegations. The tactic students use most often is questioning the women's motives for coming forward during the presidential campaign. For instance, Jack, a white junior, explains,

We want women to come forward with stories of how they were victimized, but at the same time, women are people, too. They're not angels. They can lie also, and take people out of positions.

This type of rationalization calls into question the veracity of accusers' claims and allows Trump's supporters to rationalize their continued support of him.

The majority of participants (9 out of 10) also shift attention away from the allegations against Trump to Democratic leaders, whom they perceive have engaged in unethical behaviors. For example, Bartholomew, a white freshman, reveals,

It's happened to previous presidents, too, like if Bill Clinton was willing to [be involved with] an intern in his office, he's probably willing to do some other 
stuff, too, behind the scenes...JFK had girls coming in and out of the White House constantly, people love him...we've had presidents with sexual scandals. It's not like we haven't had that.

Bartholomew neutralizes Trump by pointing to other similar examples, thus attempting to downplay Trump's misconduct. Jack, a white junior, also engages in this neutralizing tactic by shifting the attention to Hillary Clinton. He says,

Let's face it, Clinton wasn't without dirt on her...She said that Bill Clinton's accusers of rape were trash... well, way to be an outstanding character for women, be a representative for women. It's just unfortunate that people just voted for her just because she was a woman.

By condemning Clinton and framing her actions as particularly egregious, Jack and other students neutralize Trump's alleged criminal behaviors, which, in turn, allows them to justify their continued support of him. This finding supports Erichsen and colleagues' (2020) findings.

The majority of interviewees (9 out of 10) also blame the media for exaggerating and perpetuating the claims against Trump. For instance, Bartholomew, a white freshman, says, "It is simultaneously not like a perfectly acceptable, like, upstanding thing to say, but it's also not the fiasco that a lot of the media has made it out to be. It's not rape," when asked about the recording of Trump saying, "grab them by the $\mathrm{p}^{* * *} \mathrm{y}$." By articulating a "this is fake news" perspective, interviewees can more easily dismiss accusations against Trump.

Finally, although nine participants allude to the fact that Trump is not an ideal moral leader and that they may see their approval of him as deviant, they still rationalize supporting him because they believe in his policies. By foregrounding the importance of Trump's policies, interviewees downplay the seriousness of his troubling actions and the accusations against him. In essence, they look past and excuse his character because he upholds Republican policies that resonate with their conservative identities. Bambi, a white sophomore, explains,

It's a little disappointing that our president is not a role model...That has made me question a little bit, but his character as a person doesn't affect his ideas as a president and as a leader...It sucks that he's a horrible person...but in 20 years, I think that the impact he has had on our country today will be more relevant than who he was as a person.

This form of appealing to higher loyalties rationalizes continued support for Trump by disregarding his actions and lack of moral integrity for the sake of the Republican party. Studies have come to similar conclusions as conservatives are less likely to condemn a member of their in-group compared to someone in their out-group (van der Linden and Panagopoulos 2019). Ultimately, interviewees can disregard Trump's sexism and sexual misconduct by appealing to higher loyalties and by protecting their in-group, which would be Republicans or conservatives. Additionally, students employ neutralization tactics to resist the notion that their political beliefs are deviant despite the instinct for participants to conceal their support.

\section{Sense of Alienation}

Although participants did not indicate internal conflict over their support of Trump, students re- 
port that they feel alienated both on a national level via the media and at a local level on their university campus due to their endorsement. As a result of their perceived alienation and the knowledge that their support is viewed by many around them as deviant, nine of the interviewees express being hesitant to share their approval of Trump and tend to hide their political beliefs. They are aware that their support of Trump is perceived as problematic, and in response, they conceal their support on campus. Similarly, at one university, $68 \%$ of conservative students report hiding their opinions compared to only $24 \%$ of liberal students (Friedersdorf 2020). When they express their stance on Trump, interviewees report being verbally attacked or cut off from relationships. Hannah, a white senior, describes her experience, stating, "I watched myself get alienated as soon as I started openly supporting the president." She discusses losing friends both on campus and at home and how hurt she was by these developments.

Participants also reveal how the media's perceived negative treatment of Trump fosters in them profound feelings of alienation from the larger country, a feeling that they say they had never experienced previously. Six of the interviewees say that because of the negative media attention about Trump, they have experienced frustration and disaffection. For instance, Hannah, a white senior, explains,

It's frustrating to see that you're so hated. To just watch the news and hear every single news outlet talk about how Trump is Hitler...you think that's a person you support, so what am I to them? To be heard that all Trump supporters are racist...It feels hopeless in a way. Is there any chance for you to be able to be accepted in society with your political views, or do you always have to hide it?
Here, Hannah describes feeling a type of vicarious hatred; she perceives the media hate Trump, and since she supports Trump, she feels similarly vilified and persecuted. This sense of persecution leads to an increased sense of alienation and isolation where they hide their political beliefs and identity from others.

Although none of the students could identify any anti-Trump signage at their university, all participants voice feeling a sense of alienation on campus for supporting Trump. For example, Bambi, a white sophomore, reveals that "no matter whoever you talk to, no matter what classroom you're sitting in, you're probably outnumbered." As a result of such perceptions, many interviewees state that they intentionally hide their political beliefs in informal settings with friends, as well as in more formal contexts, like classrooms, with faculty and students. Multiple interviewees describe situations in classes where anti-Trump views are expressed either by faculty or other students, making interviewees hesitant to express their differing stances. Additionally, participants avoid explicitly stating their support amongst peers for fear of damaging or losing those friendships.

The negative attention Trump receives and perceived alienation on campus only strengthen interviewees' support for Trump. Half of the participants explicitly state that the marginalization they report experiencing pushes them further right politically and even more fervently in support of Trump. For example, Bambi, a white sophomore, claims that "It's [Trump's negative attention] made me want to stand up for him and to fight for him more and tell people I know he's done all this bad, but this is all he's doing that's great." Rather than being deterred by the criticism leveled against Trump, interviewees see this disparagement as a reason to double down on their support of the 
president and as a further reason to adhere to their conservative identities.

Ultimately, students report that they experience tremendous negative social costs for approving Trump. They lose friends, feel vilified at their university and in their country, and find it necessary to hide and filter their views in both informal and formal settings on campus. Instead of causing these individuals to question their beliefs, such experiences lead to more entrenched support for Trump. When asked what Trump could do to lose their support, many explain that he would have to commit an egregious act, such as murder, abuse his wife, or take on a politically left stance. Importantly, six students struggle to envision a scenario where they would not support Trump. As Bambi, a white sophomore student, explains, "I don't think he's capable of taking actions that would contradict my beliefs." Although much of the public believes that Trump has already committed egregious acts against women and many other groups, these participants explain that it would take an even more heinous act to sway their vote from Trump, indicating that it would be nearly impossible for Trump to lose their endorsement (Abrams 2019; Grady 2020; Relman 2020).

\section{Discussion and Conclusion}

This study examines how college-aged Trump supporters navigate their support of Donald Trump in a university context that they perceive to be liberal. Although previous research examines what demographics voted for Trump and the media's neutralization of Trump, my work offers a new angle by exploring the processes, justifications, and consequences of supporting Trump, a President with low approval ratings and who is seen by many as controversial (FiveThirtyEight 2020; Milligan 2020).
Through an analysis of ten semi-structured interviews with university students who identify as Trump supporters, my paper finds that students point to their resonance with a conservative worldview as a reason they came to support Trump. The salient dimensions of their conservative perspective that facilitate their support of Trump include their childhood family influence, Christian beliefs, the economic/business mindset, and a pro-life stance.

Next, to justify their continued support of Trump in light of the many sexual misconduct allegations against him, participants engage in a variety of neutralization strategies. These efforts serve to downplay the seriousness of the multiple accusations against Trump, which, in turn, allow them to more seamlessly connect their conservative identity with their ongoing support of Trump, whom some Christian leaders increasingly view as "morally lost and confused" (Bailey 2019). Interviewees neutralize Trump by believing he is more of a political and economic leader than a moral one. They also cite his upbringing, gender, and wealth as excuses for his behavior. When asked about sexual misconduct allegations, students question women's stories and emphasize the importance of due process. Some respondents go as far as minimizing Trump's sexism by explaining how he has benefitted women. All of these tactics allow participants to downplay and even disregard the seriousness of Trump's alleged sexual misconduct and rationalize their continued support of him. This finding expands Silva's (2019) work on the neutralization of Trump's racist rhetoric by focusing on Trump supporters' perceptions of his sexism and acknowledging how the alienation they experience in the aftermath of support strengthens their ties to Trump and conservatism. My findings also extend Schneider and Hannem's (2019) content analysis of the media's coverage of Trump's sexual misconduct. Conservative college students-like the media-downplay the 
impact of sexual misconduct by pointing to other facets of the accused or political figures they perceive as worse than Trump and by dismissing such allegations as false (Schneider and Hannem 2019). In addition, this finding supports past studies on the denial and justification of racism, as well as studies on the support of Trump (van Dijk 1992; van Leeuwen and Wodak 1999; Jaffe 2018; Setzler and Yanus 2018; Erichsen et al. 2020; Vescio and Schermerhorn 2020).

Unlike past scholarship, this study views a sense of alienation as both a consequence and catalyst of support. As a result of their continued support of Trump, participants perceive a tremendous sense of alienation and vilification when they hear critical stories about Trump in the national news and on social media, but also when they attempt to engage with other students and faculty on their university campus. They explain how, as a result of their feelings of alienation in their university setting, they attempt to filter their speech on campus to avoid conflict and judgment. Additionally, students double down in their belief in Trump when faced with the controversies surrounding him. Interestingly, these perceptions appear to have some overlap with feelings of white victimization and white fragility, patterns that future researchers would be well served to explore in greater detail (DiAngelo 2011; Cabrera 2014).

My study has a couple of limitations worth noting. First, the sample size is quite small and focuses solely on students at one university in the South. Secondly, I foreground conservative students' responses to Trump's sexual misconduct allegations, not his racist comments, such as calling immigrants "animals" and actions, for instance, his Muslim travel ban and push to build a wall (Hayes 2018; Long 2019). Finally, my data were collected before both of the impeachment hearings, data points that would have enhanced my overall study. Still, my paper has some notable strengths. First, I explore the perceptions and experiences of conservative students, a group that sociology as a discipline has traditionally overlooked, and link four dimensions of conservative positionality to people's support of Trump. Secondly, by applying neutralization theory to university students who support Trump, I uncover important processes that help explain why some conservative individuals continue to support Trump, even in the face of accusations of misconduct. Although my work is a case study focusing on one university, the findings help explain larger national patterns by exploring the processes involved in citizens rationalizing repeated harmful actions taken by politicians. Popular press articles suggest that similar dynamics occur in contexts outside of the academic setting, including at the recent impeachment hearings (Fandos and Edmondson 2020).

With the current political unrest and continuation of support for Trump, it is essential to understand how some voters, notably those who are white and conservative, use neutralizing strategies to justify their continued support of a controversial and, to many, highly problematic political leader. Understanding these processes more fully may also provide important insights into the ways that citizens in democracies rationalize the sexism [racism, homophobia, ethnocentrism] of their leaders through their adherence to conservative values, even in the face of widespread disapproval (Hewitt 2019; Rubin 2020).

\section{Acknowledgments}

I thank Dr. Maria Lowe (Southwestern University) for her time and mentorship throughout the research and revision process. I also thank my fellow sociology students, Hannah Bills, Sydney Hubbard, Molly McConnell, and Zac White, for their insights during peer review. 


\section{References}

Abrams, Abigail. 2019. "Here Are the Other Investigations President Trump Still Faces." Time. Retrieved July 30, 2021 (https://time.com/5557644/donald-trump-other-investigations-mueller/).

Adams, Kenneth Alan. 2019. "Trump and the Social Trance." Journal of Psychohistory 46(4):238-258.

Anderson, Greta. 2020. "Shifting Further Right." Inside Higher Ed. Retrieved January 10, 2020 (https://www.insidehighered. com/news/2020/01/07/maine-college-republican-group-movesright-alienating-some-members).

Atkinson, Lucy and Yoojung Kim. 2014. "“I Drink It Anyway and I Know I Shouldn't': Understanding Green Consumers' Positive Evaluations of Norm-Violating Non-Green Products and Misleading Green Advertising." Environmental Communication 9(1):37-57. doi: 10.1080/17524032.2014.932817.

Bailey, Sarah P. 2019. “Christianity Today, an Influential Evangelical Magazine, Says Trump 'Should be Removed from Office."' The Washington Post. Retrieved January 10, 2020 (https://www.washingtonpost.com/religion/2019/12/19/christianity-today-an-influential-evangelical-magazine-says-president-trump-should-be-removed-office/).

Berlinerblau, Jacques. 2019. “Donald J. Trump, the White Evangelicals, and Martin Luther: A Hypothesis." Interpretation: A Journal of Bible \& Theology 73(1):18-30.

Binder, Amy and Kate Wood. 2013a. "Who Are Conservative Students?" Pp. 29-75 in Becoming Right: How Campuses Shape Young Conservatives. Princeton, Oxford: Princeton University Press.

Binder, Amy and Kate Wood. 2013b. "How Conservatives Think about Campus: The Effects of College Reputations, Social Scenes, and Academics on Student Experience." Pp. 111160 in Becoming Right: How Campuses Shape Young Conservatives. Princeton, Oxford: Princeton University Press.

Blackett, Emma. 2017. "'Sexism Defeated!': Women for Trump and the Binding Energy of Political Hope." Women's Studies Journal 31(2):18-26.

Boyle, Kaitlin M. and Ashleigh E. McKinzie. 2015. “Resolving Negative Affect and Restoring Meaning: Responses to Deflec- tion Produced by Unwanted Sexual Experiences." Social Psychology Quarterly 78(2):151-172. doi: 10.1177/0190272514564073.

Boyle, Kaitlin M. and Lisa Slattery Walker. 2016. “Neutralization and Denial of Sexual Violence in College Party Subcultures." Deviant Behavior 37(12):1392-1410. doi: 10.1080/01639625.2016.1185862.

Cabrera, Nolan L. 2014. “Exposing Whiteness in Higher Education: White Male College Students Minimizing Racism, Claiming Victimization, and Recreating White Supremacy." Race, Ethnicity, and Education 17(1):30-35.

Cohen, Andrew. 2017. "Psychological Harm and Free Speech on Campus." Society 54(4):320-325.

DiAngelo, Robert. 2011. "White Fragility." International Journal of Critical Pedagogy 3(3):54-70.

Dickerson, Caitlin and Stephanie Saul. 2016. “Campuses Confront Hostile Acts against Minorities after Donald Trump's Election." The New York Times. Retrieved January 14, 2020 (https://www.nytimes.com/2016/11/11/us/police-investigate-attacks-on-muslim-students-at-universities.html).

Dijk, Teun, van. 1992. "Discourse and the Denial of Racism." Discourse E Society 3(1):87-118.

Edgell, Penny. 2017. “An Agenda for Research on American Religion in Light of the 2016 Election." Sociology of Religion 78(1):1-8.

Erichsen, Kristen et al. 2020. “Bitchifying Hillary: Trump Supporters' Vilification of Clinton during the 2016 Presidential Election." Social Currents 7(6):526-542.

Fahrenthold, David. 2016. “Trump Recorded Having Extremely Lewd Conversation about Women in 2005." The Washington Post. Retrieved January 15, 2020 (https://www.washingtonpost. com/politics/trump-recorded-having-extremely-lewd-conversation-about-women-in-2005/2016/10/07/3b9ce776-8cb4-11e6bf8a-3d26847eeed4_story.html).

Fandos, Nicholas and Catie Edmondson. 2020. "As a Post-Impeachment Trump Pushes the Limits, Republicans Say Little." The New York Times. Retrieved February 19, 2020 (https://www. nytimes.com/2020/02/12/us/politics/trump-senate-republicans. html). 
FiveThirtyEight. 2020. "How Popular is Donald Trump?" Retrieved January 11, 2020 (https://projects.fivethirtyeight.com/ trump-approval-ratings/).

Friedersdorf, Conor. 2020. "Evidence that Conservative Students Really do Self-Censor: Is Free Speech Imperiled on American College Campuses?" The Atlantic. Retrieved February 21, 2020 (https://www.theatlantic.com/ideas/archive/2020/02/evidence-conservative-students-really-do-self-censor/606559/).

Frumin, Aliyah. 2016. "After Clinton Loss, \#NotMyPresident, \#StillWithHer Goes Viral." NBC News. Retrieved December 09, 2019 (https://www.nbcnews.com/news/us-news/after-clinton-loss-notmypresident-stillwithher-goes-viral-n681446).

Gainor, Dan. 2016. "Liberals Get Hysterical over the 'Alt-Right' but We Are Living in Their 'Alt-Left' World." Fox News. Retrieved December 28, 2019 (https://www.foxnews.com/opinion/ liberals-get-hysterical-over-the-alt-right-but-we-are-living-intheir-alt-left-world).

Gainor, Dan. 2017. "Liberals (and the Media) are Finally Getting the Violence They Wanted." Fox News. Retrieved January 14, 2020 (https://www.foxnews.com/opinion/liberals-and-themedia-are-finally-getting-the-violence-they-wanted).

Grady, Constance. 2020. “E. Jean Carroll Says Trump Raped Her. She's Suing Him. Now She's Been Fired from Elle." Vox. Retrieved February 23, 2020 (https://www.vox.com/culture/2020/2/19/21144280/e-jean-carroll-elle-fired-trump-defamation-lawsuit).

Gross, Neil, Thomas Medvetz, and Rupert Russell. 2011. “The Contemporary American Conservative Moment." Annual Review of Sociology 37:325-354.

Gummadam, Parveena, Laura D. Pittman, and Micah Ioffe. 2016. "School Belonging, Ethnic Identity, and Psychological Adjustment among Ethnic Minority CollegeStudents." The Journal of Experimental Education 84(2):289306. doi: 10.1080/00220973.2015.1048844.

Hartocollis, Anemona. 2016. “On Campus, Trump Fans Say They Need 'Safe Spaces.'” The New York Times. Retrieved October 18, 2019 (https://www.nytimes.com/2016/12/08/us/politics/ political-divide-on-campuses-hardens-after-trumps-victory. html).

Hayes, Christal. 2018. "Here Are Ten Times President Trump's Comments Have Been Called Racist." USA Today. Retrieved January 11, 2020 (https://www.usatoday.com/story/news/pol- itics/onpolitics/2018/08/14/times-president-trump-commentscalled-racist/985438002/).

Hewitt, Hugh. 2019. "Why Do Conservatives Support Trump? Because He Implements Conservative Policies." The Washington Post. Retrieved January 09, 2020 (https://www.washingtonpost.com/opinions/2019/10/12/why-do-conservatives-support-trump-because-hes-conservative-president/).

Hills, Darrius. 2018. “Back to a White Future: White Religious Loss, Donald Trump, and the Problem of Belonging." Black Theology: An International Journal 16(1):38-52.

Jaffe, Sarah. 2018. "Why Did a Majority of White Women Vote for Trump?" New Labor Forum 27(1):18-26.

Johnson, Emily Suzanne. 2019. “Women Have Been the Heart of the Christian Right for Decades." The Conversation. Retrieved October 09, 2019 (http://theconversation.com/women-havebeen-the-heart-of-the-christian-right-for-decades-118094).

Johnson, Jessica. 2019. "When Hate Circulates on Campus to Uphold Free Speech." Studies in Law, Politics \& Society 80:113130.

Jones, Jeffery M. 2018. “More U.S. College Students Say Campus Climate Deters Speech." Gallup. Retrieved February 12, 2020 (https://news.gallup.com/poll/229085/college-studentssay-campus-climate-deters-speech.aspx).

Junn, Jane. 2017. "The Trump Majority: White Womanhood and the Making of Female Voters in the U.S." Politics, Groups, and Identities 5(2):343-352.

Kaplan, Adiel et al. 2019. "Trump Admin Files More Briefs in Religious Liberty Cases than Obama, Bush." NBC News. Retrieved January 11, 2020 (https://www.nbcnews.com/politics/ justice-department/trump-admin-files-more-briefs-religiousliberty-cases-obama-bush-n974531).

Kaptein, Muel and Martien Helvoort, van. 2019. "A Model of Neutralization Techniques." Deviant Behavior 40(10):1260-1285. doi: 10.1080/01639625.2018.1491696.

Keneally, Meghan. 2019. “List of Trump's Accusers and Their Allegations of Sexual Misconduct." abc News. Retrieved December 29, 2020 (https://abcnews.go.com/Politics/list-trumps-accusers-allegations-sexual-misconduct/story?id=51956410).

Kidder, Jeffrey L. 2016. "College Republicans and Conservative Social Identity." Sociological Perspectives 59(1):177-200. 
Klein, Josh and Cathryn Lavery. 2010. "Presidential Candidates and State Crime: Views of Some U.S. College Students." Critical Criminology 18(3):191-209. doi: 10.1007/s10612-010-9097-5.

Kolber, Jess. 2017. "Having It Both Ways: White Denial of Racial Salience while Claiming Oppression." Sociology Compass 11(2):1-9. doi: 10.1111/soc4.12448.

Leeuwen, Theo, van and Ruth Wodak. 1999. "Legitimizing Immigration Control: A Discourse-Historical Analysis." Discourse Studies 1(1):83-118.

Lemire, Jonathan and Elana Schor. 2020. "Trump Portrays Himself as Defender of Faith for Evangelical Supporters at Miami Rally." TIME. Retrieved January 11, 2020 (https:/time. com/5758805/trump-rally-miami-evangelical/).

Linden, Sander, van den and Costas Panagopoulos. 2019. "The O'Reilly Factor: An Ideological Bias in Judgments about Sexual Harassment." Personality and Individual Differences 139:198-201.

Long, Colleen. 2019. “Analysis: 'Go Back' Captures Core of Trump Political Agenda." Associated Press. Retrieved January 11, 2020 (https://apnews.com/f106b3351f6148a98f8f24c536f464ed).

Marx, Karl. 2013. “Estranged Labour.” Pp. $32-38$ in Social Theory: The Multicultural Readings, edited by C. Lemert. Philadelphia: Westview Press.

McGraw, Meridith. 2019. "Trump Airs His Grievances as MAGA Millennials Mingle." Politico. Retrieved January 10, 2020 (https://www.politico.com/news/2019/12/21/trump-turning-point-usa-speech-089182).

Merriman, Ben. 2019. Conservative Innovators: How States Are Challenging Federal Power. Chicago: University of Chicago Press.

Milligan, Susan. 2020. "Support for Trump's Removal Grows." U.S. News \& World Report. Retrieved January 11, 2020 (https:// www.usnews.com/news/politics/articles/2020-01-03/supportfor-trumps-impeachment-removal-grows-in-new-survey).

Munson, Ziad. 2010. “Mobilizing on Campus: Conservative Movements and Today's College Students." Sociological Forum 25(4):769-786.

Pruitt, Lisa R. 2018. “The Women Feminism Forgot: Rural and Working-Class White Women in the Era of Trump." University of Toledo Law Review 49(3):537-604.
Reimer, Erich. 2017. "Stop Saying 'Not My President.'” The Washington Examiner. Retrieved January 14, 2020 (https://www. washingtonexaminer.com/stop-saying-not-my-president).

Relman, Eliza. 2020. "The 26 Women Who Have Accused Trump of Sexual Misconduct." Business Insider. Retrieved December 29, 2020 (https://www.businessinsider.com/women-accused-trump-sexual-misconduct-list-2017-12?IR=T).

Renfrow, Daniel G. and Elisabeth A. Rollo. 2014. "Sexting on Campus: Minimizing Perceived Risks and Neutralizing Behaviors." Deviant Behavior 35(11):903-920. doi: 10.1080/01639625.2014.897122.

Rogers, Katie. 2016. "Pro-Trump Chalk Messages Cause Conflicts on College Campuses." The New York Times. Retrieved December 29, 2019 (https://www.nytimes.com/2016/04/02/us/ pro-trump-chalk-messages-cause-conflicts-on-college-campuses.html).

Rubin, Jennifer. 2020. “Sorry, Trump. Most Americans Don't Like You." The Washington Post. Retrieved January 11, 2020 (https://www.washingtonpost.com/opinions/2020/01/02/americans-dont-believe-or-like-trump/).

Schneider, Christopher J. and Stacey Hannem. 2019. "Politicization of Sexual Misconduct as Symbolic Annihilation: An Analysis of News Media Coverage of the 2016 'Rape Election."' Sexuality \& Culture 23(3):737-759.

Schwadel, Philip and Gregory A. Smith. 2019. “Evangelical Approval of Trump Remains High, but Other Religious Groups Are Less Supportive." Pew Research Center. Retrieved February 18, 2020 (https://www.pewresearch.org/fact-tank/2019/03/18/ evangelical-approval-of-trump-remains-high-but-other-religious-groups-are-less-supportive/).

Seeman, Melvin. 1959. “On the Meaning of Alienation." American Sociological Review 24(6):783-791.

Setzler, Mark and Alixandra B. Yanus. 2018. "Why Did Women Vote for Donald Trump?" Political Science and Politics 51(3):523-527.

Shammas, Diane. 2015. “We Are Not All the Same: Arab and Muslim Students Forging Their Own Campus Communities in a Post9/11 America." Journal of Muslim Minority Affairs 35(1):65-88.

Silva, Eric O. 2019. “Accounting for Trump: The Neutralization of Claims of Racism in the Early Stages of the 2016 Presidential Campaign." Pp. 197-216 in Studies in Symbolic Interaction, vol. 50, edited by N. K. Denzin. Emerald Publishing Limited. 
Spencer, Kyle. "The Rise of the Battleground Campus." Politico. Retrieved January 02, 2020 (https://www.politico.com/news/ magazine/2019/11/15/2020-election-college-campus-politics-batt leground-states-070076).

Sykes, Gresham M. and David Matza. 1957. "Techniques of Neutralization: A Theory of Delinquency." American Sociological Review 22(6):664-670.

Tachine, Amanda R., Nolan L. Cabrera, and Eliza Yellow Bird. 2017. "Home Away From Home: Native American Students' Sense of Belonging During Their First Year in College." Journal of Higher Education 88(5):785-807.

Tien, Charles. 2017. "The Racial Gap in Voting among Women: White Women, Racial Resentment, and Support for Trump." New Political Science 39(4):651-669.

Trump, Donald. 2018. "President Donald J. Trump Is Defending American Values." The White House. Retrieved January 11,
2020 (https://trumpwhitehouse.archives.gov/briefings-statements/president-donald-j-trump-defending-american-values/?utm_source=link).

Vescio, Theresa and Nathaniel Schermerhorn. 2020. "Hegemonic Masculinity Predicts 2016 and 2020 Voting and Candidate Evaluations." Proceedings of the National Academy of Sciences 118(2):1-10.

Woessner, Matthew and Robert Maranto. 2019. "Campus Conservatives Aren't under Siege but There's More to the Story." NBC News. Retrieved January 10, 2020 (https://www.nbcnews. com/think/opinion/right-says-campus-conservatives-are-under-siege-left-dismissive-both-ncna1042051).

Wootson, Cleve R., Jr. 2017. "She Wanted to Criticize Black Lives Matter in a College Speech. A Protest Shut Her Down." The Washington Post. Retrieved January 14, 2020 (https://www. washingtonpost.com/news/grade-point/wp/2017/04/10/shewanted-to-criticize-black-lives-matter-in-a-college-speech-aprotest-shut-her-down/).

\section{APPENDICES}

\section{Interview Schedule}

\section{Background Questions}

1. Can you tell me about the kind of political views of your family during childhood? If any.

2. Do your parents support President Trump? Grandparents? Others in your family?

- How has this impacted your views?

3. Would you say you had a politically diverse upbringing?

- Why?

- What impact did this have on your views?

4. Tell me about a time when political issues were discussed in your childhood home?

5. Were politics important in your home, or were they a point of contingency?

6. How would you describe the political makeup of your high school?

7. Did you have open political discussions in high school?

8. Tell me about what it was like to have political discussions at your high school?

- Did they lean a certain way, or were they unbiased?

9. How do you think your upbringing impacted the views you hold today?

\section{Questions about Personal Views}

10. Why do you support President Trump?

11. What are some specific examples of President Trump's leadership that have led you to support him?

12. How does President Trump reflect your views?

13. What are some of President Trump's specific policies that you support? 


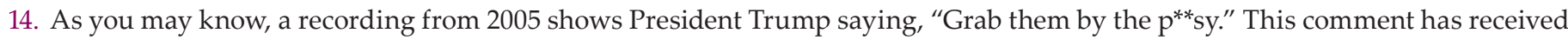
a lot of negative attention from the media and from those who do not support him. What are your thoughts on President Trump's statement, "Grab them by the $\mathrm{p}^{* *}$ sy?"

- Did this recording cause you to doubt or confirm your support at all? If so, how?

- Do you think the media covered this event accurately?

- How do you think this comment was perceived by women who have experienced sexual assault?

- How did you perceive this incident as a woman?

- Did you find it offensive? Why, or why not?

15. In general, do you think the media portrays President Trump accurately?

16. What do you think of President Trump's presidency thus far?

- Would you say he is doing as expected, better, or worse?

17. Have you ever doubted your support for President Trump? If so, when and why?

18. As you may know, around 15 women have recently come forward accusing President Trump of sexual harassment and misconduct. Such as Samantha Holvey, the former Miss North Carolina, who claims President Trump inspected beauty pageant contestants. Jessica Leeds has also accused President Trump of grabbing her chest and attempting to put his hand up her skirt during a flight. What are your thoughts regarding these accusations?

- How do you feel about the women who have accused President Trump of sexual misconduct?

- Why do you think women have come forward?

- Have these accusations made you doubt your support at all? If so, how?

19. As you may know, President Trump's former personal lawyer, Michael Cohen, recently testified before the House Oversight Committee. Cohen testified that President Trump instructed him to make payments to two women who claim to have had sexual affairs with President Trump to buy their silence. This would constitute an illegal campaign contribution. What are your thoughts on Cohen's testimony?

- Has Cohen's testimony impacted your views on President Trump? How?

- What are your thoughts on the women who claim to have had sexual affairs with President Trump?

20. How has the negative attention President Trump has received impacted your views, if at all?

21. Does President Trump uphold your values and morals? How?

22. What are some specific examples of things President Trump has done to earn your support?

23. Do you think Trump represents the United States well? Why?

24. How do you perceive opinions that view President Trump as degrading or sexist?

25. Do you think Trump respects women? Why, or why not?

- If so, in what ways has President Trump shown respect for women?

26. Do you think your support for President Trump has impacted relationships in your life? How?

27. How could President Trump lose your support?

28. Would you say policies are more important than individual character when it comes to deciding whom to vote for?

\section{Questions about the University}

29. Given that [university name] has a reputation for being liberal, do you seek out other students on campus who also support President Trump?

30. How has college swayed or confirmed your support for President Trump, if at all?

31. Do you feel comfortable expressing your political views on campus? Why, or why not?

32. Tell me about a specific time when you felt comfortable expressing your views on campus.

33. Tell me about a specific time when you felt uncomfortable expressing your views on campus.

34. Tell me about a time you had discussions regarding President Trump with other [university name] students? Explain.

35. Has President Trump been discussed in your classes?

- Can you tell me about a specific example?

- What do you do when this happens? Do you voice or hide your opinions?

- How have these discussions made you feel?

36. Have you ever felt attacked in the classroom for your support of President Trump?

37. Has a professor ever talked with you about your support for President Trump?

- How did this make you feel? 
38. Do you think the [university name] student body is majority anti-Trump or pro-Trump? Why?

39. Have you ever been shamed for your views on campus? Can you provide an example?

40. What changes, if any, would you want to see at [university name] regarding the political climate?

Questions about Future

41. How do you think President Trump will change the future of politics for the better? For the worse?

42. What do you hope to see in the future for politics?

43. What do you hope to see in the future for women's rights?

44. How do you think President Trump can impact women's rights?

\section{Demographic Questions}

45. How old are you?

46. What race do you identify as?

47. What ethnicity do you identify as?

48. What extracurricular activities are you involved in?

49. What is your hometown?

50 . What is your major?

51. What social class do you belong to?

52. What political party do you belong to, if any?

\section{Table 1. Interviewees' Demographics}

\begin{tabular}{|c|c|c|c|c|}
\hline Pseudonym & Political Identity & Race & Gender & Interview Length \\
\hline Anne & Republican & White & Female & 1 hour, 23 minutes \\
\hline Kendall & Republican & White/Hispanic & Female & 42 minutes \\
\hline Bambi & Republican & White & Female & 1 hour, 2 minutes \\
\hline Hannah & Republican & White/Hispanic & Female & 50 minutes \\
\hline Annabelle & Republican & White & Female & 1 hour, 6 minutes \\
\hline Jack & Independent & White & Male & 1 hour, 24 minutes \\
\hline Andrea & Independent & White & Female & 41 minutes \\
\hline Carlos & Independent & White & Male & 1 hour, 8 minutes \\
\hline John & Independent & White & Male & 46 minutes \\
\hline Bartholomew & Independent & White & Male & 1 hour, 50 minutes \\
\hline
\end{tabular}

Source: Self-elaboration.

\section{Citation}

Adams, Madison. 2021. "Supporting the President in a \#NotMyPresident Context: Experiences of College-Aged Trump Supporters at a Southern University." Qualitative Sociology Review 17(4):82-102. Retrieved Month, Year (http://www.qualitativesociologyreview.org/ENG/archive_eng.php). DOI: https://doi.org/10.18778/1733-8077.17.4.05 